\title{
Six decades of educational multilateralism in a globalising world: The history of the UNESCO Institute in Hamburg
}

\author{
Maren Elfert
}

Published online: 25 May 2013

(C) Springer Science+Business Media Dordrecht 2013

\begin{abstract}
Created in 1945 as a specialised agency of the United Nations (UN), the United Nations Educational, Scientific and Cultural Organization (UNESCO) was given, among other mandates, the task of reconstructing education systems devastated during the Second World War. UNESCO, in turn, and after some debate about an engagement in Germany, founded the UNESCO Institute for Education (UIE) in Hamburg in 1952. This paper traces the development of an institute which was founded to contribute to social renewal in war-torn Germany and Europe, functioned as a mediator between Western and Eastern countries during the Cold War and later shifted its geographical focus to developing countries. The institute was instrumental in conceptualising lifelong learning as a global educational paradigm, as well as in shaping the shift from education to learning and the concept of literacy as a "continuum". The author is particularly interested in the nature of the institute's niche which secured its survival in the uncertain domain of educational multilateralism in the past six decades.
\end{abstract}

Keywords UNESCO - UNESCO Institute for Education - UNESCO Institute for Lifelong Learning · Adult education · Lifelong education · Lifelong learning · Literacy $\cdot$ CONFINTEA

Résumé Soixante ans de multilatéralisme éducatif dans un contexte de mondialisation : le parcours de l'Institut de l'UNESCO à Hambourg - Agence spécialisée des Nations Unies (ONU) créée en 1945, l'Organisation des Nations Unies pour l'éducation, la science et la culture (UNESCO) a été chargée, entre autres mandats, de reconstruire les systèmes éducatifs dévastés par la Seconde Guerre mondiale. L’UNESCO à son tour, après quelques débats sur un engagement en Allemagne, a

\footnotetext{
M. Elfert $(\bowtie)$

Department of Educational Studies, Faculty of Education, University of British Columbia, Vancouver, BC, Canada

e-mail: elfertm@shaw.ca
} 
inauguré en 1952 à Hambourg l'Institut de l'UNESCO pour l'Éducation (IUE). Le présent article retrace le parcours d'un institut fondé pour contribuer au renouvellement social dans l'Allemagne et l'Europe déchirées par la guerre, qui a fait office de médiateur entre les pays de l'Ouest et de l'Est pendant la guerre froide, et plus tard réorienté sa dominante géographique au profit des pays en développement. L'Institut a joué un rôle déterminant en ce qu'il a conceptualisé l'apprentissage tout au long de la vie en tant que modèle éducatif universel, et façonné le passage de l'éducation à l'apprentissage ainsi que le concept de l'alphabétisation en tant que continuum. L'auteure examine en particulier la nature du créneau qui a assuré la survie de l'Institut au cours des 60 dernières années dans le domaine incertain du multilatéralisme éducatif.

Zusammenfassung Sechzig Jahre multilaterale Bildungspolitik im Zeichen der Globalisierung: Die Geschichte des Hamburger UNESCO-Instituts - Nach ihrer Gründung als Sonderorganisation der Vereinten Nationen (UNO) im Jahr 1945 hatte die Organisation der Vereinten Nationen für Bildung, Wissenschaft und Kultur (UNESCO) unter anderem den Auftrag, die im Zweiten Weltkrieg zugrunde gerichteten Bildungssysteme wieder aufzubauen. Die UNESCO wiederum gründete, nach einigem Hin und Her über einen Standort in Deutschland, 1952 das UNESCO Institute for Education (UIE) in Hamburg. In diesem Beitrag wird die Entwicklung eines Instituts nachgezeichnet, das zunächst die gesellschaftliche Erneuerung in dem vom Krieg zerrütteten Deutschland und Europa fördern sollte, das im Kalten Krieg als Mittler zwischen West und Ost fungierte, um sich danach auf die Entwicklungsländer zu konzentrieren. Das Institut war maßgebend für die Entwicklung des Konzepts des lebenslangen Lernens als globales Bildungsmodell, es verlagerte den Fokus vom Erziehungs- auf den Lernprozess und prägte das Konzept der Alphabetisierung als „Kontinuum“. Die Autorin interessiert sich insbesondere dafür, in welcher Nische es dem Institut gelungen ist, auf dem schwierigen Feld der multilateralen Bildungspolitik in den letzten sechs Jahrzehnten zu bestehen.

Resumen Seis décadas de multilateralismo educativo en un mundo globalizante: La historia del Instituto de la UNESCO en Hamburgo - Creada en 1945 como organismo especializado de las Naciones Unidas (ONU), a la Organización de las Naciones Unidas para la Educación, la Ciencia y la Cultura (UNESCO) se le adjudicó, entre otras tareas, la de reconstruir los sistemas educativos que habían quedado devastados durante la Segunda Guerra Mundial. Por otra parte, y tras algunos debates sobre si la UNESCO debía o no involucrarse con su trabajo en Alemania, finalmente se estableció en Hamburgo, en 1952, el Instituto de la UNESCO para la Educación (UIE). En este trabajo, la autora sigue el desarrollo de este Instituto que había sido fundado para contribuir a la renovación social en una Alemania y una Europa destruidas por la guerra, que funcionó como mediador entre los países occidentales y orientales durante la Guerra Fría y que luego desplazó su foco geográfico hacia los países en desarrollo. El Instituto tuvo una participación esencial en la conceptualización del aprendizaje a lo largo de toda la vida como paradigma educativo global, así como en el diseño de un cambio de énfasis de la educación hacia el aprendizaje y del concepto de alfabetización como continuum. 
La autora se interesa, en particular, por la naturaleza de nicho que ocupa el Instituto, esa posición específica que durante las seis décadas pasadas le ha asegurado la supervivencia en el ámbito tan incierto del multilateralismo educativo.

Резюме Шестьдесят лет мультилатерализма в области образования в условиях мировой глобализации: история Института ЮНЕСКО в Гамбурге Созданная 1945 г. в качестве специализированного агентства Организации объединённых наций (OOH), Организация объединённых наций по вопросам образования, науки и культуры, среди прочего, была наделена мандатом возрождения систем образования, разрушенных в ходе Второй мировой войны. В свою очередь, ЮНЕСКО после некоторых дебатов относительно своей роли в Германии, учредила в 1952 г. в Гамбурге Институт по вопросам образования под эгидой ЮНЕСКО. В данной статье прослеживается история развития этого института, созданного с целью содействия процессу социального возрождения разрушенных войной Германии и Европы в целом, который являлся посредником между западными и восточно-европейскими странами в период «холодной войны», а затем переместил географический фокус своего внимания на развивающиеся страны. Институт играл решающую роль в разработке концепции «непрерывного образования на протяжении всей жизни» в качестве глобальной образовательной парадигмы, а также в содействии смещения приоритетов от образования к обучению и утверждению концепции грамотности в качестве «континуума». Автора, в частности, интересует вопрос о том, каким образом институту удалось найти свою «нишу», обеспечившую его жизнеспособность в условиях нестабильности в сфере образовательного мультилатерализма в последние шесть десятилетий.

\section{Introduction}

In the aftermath of the Second World War, multilateralism emerged as the new world order and international institutions were created with the mandate of keeping peace, protecting human rights and promoting international cooperation. The United Nations Educational, Scientific and Cultural Organization (UNESCO) was founded in this context in 1945 as a specialised agency of the United Nations (UN).

Some years later, in 1952, UNESCO established the UNESCO Institute for Education (UIE) ${ }^{1}$ in Hamburg, Germany. The history of this institute is worth recalling for several reasons. The institute made major contributions to the field of adult education worldwide. Its history shows how debates about lifelong learning from a global perspective have developed from the post-World War II period until today. It reflects the interplay of ideas, institutions and people in shaping international cooperation in education in the context of global politics. UIE survived many crises caused by financial constraints and competition with

\footnotetext{
1 Today, the institute is known as the UNESCO Institute for Lifelong Learning (UIL).
} 
UNESCO headquarters in Paris, the other UNESCO education institutes ${ }^{2}$ and other "global governors" of education (Mundy 2010). The guiding question of this article is: What is the nature of the niche occupied by the institute that secured its survival in the uncertain domain of educational multilateralism in the past six decades?

This paper draws on archival research I undertook over a decade ago for a publication about the history of UIE (Elfert 2002), for which I examined primary sources from the early years of the institute. These include letters and communications with regard to the establishment of the institute; reports of meetings of the Governing Board, newspaper articles and speeches. For this paper I have expanded this research by the study of more primary sources and in particular secondary sources from a broader time period.

\section{Why UIE was founded}

One of the purposes of UNESCO in its early years was the reconstruction of devastated education systems (UNESCO 1948c, p. 4). The Second General Conference of UNESCO, held in 1948 in Mexico, examined the possibility of extending UNESCO's work to the former enemy states, Germany and Japan (UNESCO 1948a, p. 2; UNESCO 1948b, p. 3). The question of UNESCO's involvement in Germany was a much debated one between 1948 and 1950, and news about its progress often made it to the front page of the organisation's magazine, the UNESCO Courier. A "UNESCO Committee of Experts on German Questions" was called, and a UNESCO office was established in Stuttgart under the direction of John W. Thompson (UNESCO 1949a, p. 3). ${ }^{3}$

The extension of UNESCO's work in Germany was one of the "big policy issues" (UNESCO 1949b, p. 18) of the Fourth General Conference, held in September 1949. Those member states whose population had suffered the most from the war and the holocaust were opposed to an UNESCO engagement in Germany. The heated debates, in the course of which the delegates of Czechoslovakia, Hungary and Poland left the meeting and threatened to withdraw their countries' UNESCO membership, revolved around two questions: As UNESCO was unable to establish contact with the Russian zone, was UNESCO supporting the division of Germany by limiting its work to the Western zones; and was any attempt to democratise Germany worthwhile given the prevailing spirit of "nationalism" and "nazism" (ibid., p. 19) in the country? Ultimately, the General Conference voted for a continuation of the UNESCO programme in Germany. Thirty-five member states voted in favour; four dissented (the above-mentioned countries and Israel) and there was one abstention (Mexico) (ibid., p. 4).

\footnotetext{
2 Today, there are seven UNESCO education institutes and centres. For more information see http://www.unesco.org/new/en/unesco/about-us/where-we-are/institutes-and-centres/.

3 The Canadian physician John W. Thompson had been hired in 1947 as a special consultant for matters of re-education, and in 1949 he was appointed UNESCO's Permanent Commissioner for Germany. For more information about the eventful life of John W. Thompson, see Paul J. Weindling's excellent biography (Weindling 2010).
} 
The Memorandum concerning the German Problem, submitted to UNESCO by the Norwegian consultant Odd Nansen, called for "a network of centres throughout Germany for spiritual and moral rehabilitation" (UNESCO 1950b, Annex I, p. 1) in order to improve the situation of the young people in the country. As a consequence, the "UNESCO Committee of Experts on German Questions" recommended the creation of "three special projects", namely an "International Institute for Youth Activities; [an] International Institute for Social Sciences; [and an] International Institute for Pedagogy" (UNESCO 1950a, p. 2) in Germany. ${ }^{4}$ The committee further recommended that "the international character of the institutes be ensured not only through the composition of their governing bodies but also by as many countries as possible being represented on their staffs and taking part in their work" (ibid., Annex I, p. 3). In January 1951 the Executive Board of UNESCO decided to move ahead with the creation of the three centres in Germany. Initial funding for the centres was received from France, Lebanon, the Philippines and the United States (UNESCO 1951, p. 12).

Despite the resistance John Thompson encountered concerning the engagement of UNESCO in Germany among the Allied authorities, and power plays and staff changes within UNESCO which constantly jeopardised his work (Weindling 2010), he not only led the negotiations and coordinated the logistics for the founding of the three institutes but also conceptualised their respective roles and mandates. He was the driving force behind the creation of the "German Committee for UNESCO" 5 and organised, in February 1951, a meeting in Wiesbaden ${ }^{6}$ involving members of the committee - German educational experts and officials - to discuss logistical, legal and financial conditions for the foundation of the three institutes. It was decided that "Unesco should act as founder" of the "three foundations with legal status within the meaning of the German Civil Code" (Hausmann 1979, p. 5).

Thompson was instrumental in setting up the institutes' Governing Boards, on which he wanted "the finest minds and spirits" (Weindling 2010, p. 191). The Board of the Institute for Education, which was nominated by UNESCO's DirectorGeneral, was composed of six German and seven non-German representatives from Europe and North America, all of them renowned education specialists and university professors, including Maria Montessori and Jean Piaget, representing a variety of educational fields.

The first meeting of the Governing Board of the new UNESCO Institute for Education, held from 17 to 19 June 1951 in Wiesbaden, addressed the major issues

\footnotetext{
${ }^{4}$ The "International Institute for Youth Activities" was realised in the UNESCO Youth Institute in Gauting near Munich (1952-1965). The "International Institute for Social Sciences" was realised in the UNESCO Institute for Social Sciences in Cologne (1952-1960). The "International Institute for Pedagogy" was realised in UIE in Hamburg, the only one of the three institutes still in existence.

5 This committee emerged from a meeting in Bad Soden in January 1950, in which Thompson had gathered the West German intellectual community interested in cooperation with UNESCO. After the Federal Republic of Germany had become a member of UNESCO on 11 July 1951, the German Commission for UNESCO emerged from this body (see Deutsche UNESCO-Kommission 2001, pp. 160-171).

${ }^{6}$ The new UNESCO office in Wiesbaden centralised the first UNESCO office in Stuttgart (opened in 1948 in the American zone) and two others that existed in the French zone (Mainz) and the British zone (Düsseldorf) (Weindling 2010, p. 190; Deutsche UNESCO-Kommission 2001, p. 157).
} 
accompanying its establishment: The institute's relation to UNESCO headquarters and the institute's autonomy; the integration of the "German" and "international" perspectives of the institute's work; and the focus of the institute's programme. The representative of the Director-General, Lionel Elvin, pointed out that the work of the institute should not overlap with the work of UNESCO in Paris or the International Bureau of Education (IBE) in Geneva. ${ }^{7}$ In Elvin's view, the work of UIE should be relevant for all countries, but should in particular benefit its host country. German representatives expressed their concern about possible conflicts with the German education authorities and called for "tactfulness" in order to sustain the institute's autonomy (UIE 1951).

The question to what extent the institute was being established to support Germany or to work internationally was ambiguous. Already in 1948 UNESCO's Director-General Julian Huxley wrote in a personal report on UNESCO's activities in the UNESCO Courier: "We are undertaking work in Germany, not for Germany" (UNESCO 1948c, p. 1, emphasis added). The "German Committee for UNESCO" had commissioned a discussion paper about the establishment of the educational institute, written by Ms I. Giron. The 16-page document, entitled The Institute for International Work in Education, stressed the international dimension of the institute and made clear that re-education was not among its mandates: "Unless the international character of the Institute is maintained in its structure, its activities and its aims, it will have little, if any raison d'être" (cited in Hausmann 1979, p. 7).

With regard to the institute's future areas of work, all of its Governing Board members had different visions, ranging from adult education (Johannes Novrup), ${ }^{8}$ vocational education, textbooks, languages and human rights (Georg Eckert), psychology (Karl Stern), international understanding (Hans Wenke) to early childhood education (Maria Montessori). Friedrich Schneider introduced a perspective of lifelong learning when he suggested that the institute should be concerned with all age groups and that boundaries between the different fields of work should be avoided altogether (UIE 1951). In the idealist spirit of that time, marked by the trauma of the Second World War and the Holocaust, the institute's founders emphasised the value of the human being. Novrup insisted on "the very development of man as a human being" (Skovmand 1962, p. 132). Thompson believed that, "unless the single individual was accorded infinite value, another holocaust would arise" (Weindling 2010, p. 312). Maria Montessori said in her speech before the first meeting of UIE's Governing Board in 1951: "If the Institute is justified in existing, then it is only in pioneering a new path for education, that is to say one for education as a support to the inner life of man ... the school should not be the objective of this Institute but people, the whole person, and this person begins at birth" (Montessori 1992, p. 50).

\footnotetext{
7 The IBE, founded in 1925 in Geneva as a private initiative, was the first intergovernmental organisation in the field of education. It had been organising the International Conference on Education (ICE) since 1934; from 1946 onwards this conference was convened in cooperation with UNESCO.

8 Johannes Novrup was one of the leading figures of the Danish adult education movement and Chairperson of the first International Conference on Adult Education (CONFINTEA I), held by UNESCO in Elsinore, Denmark in 1949.
} 
The Constitution that the newborn UIE was given by its Governing Board reflects the role the institute was supposed to play in Germany as well as its affiliation with UNESCO and set down international understanding as one of its key tasks. The mandate of the institute was defined as: "establishing contacts between educators in Germany and other countries ... without prejudice arising from national, racial or cultural differences", and "to participate in the work of UNESCO ... to maintain peace in the world and to carry out educational programmes for international understanding" (UIE 1952a). After competition with Freiburg, which was initially favoured as site of the institute by Huxley's successor, Jaime Torres Bodet, the institute finally settled in Hamburg. ${ }^{9}$ Contributions from UNESCO member states for the institute had added up to DM $740,000^{10}$ and the Governing Board prepared the work plan of the institute for the first two years on the basis of this amount (UIE 1953, p. 9).

The first two international seminars held by UIE, on adult education in 1952 and on early childhood education in 1953, reflected the influence of Johannes Novrup and Maria Montessori. The Governing Board saw these two topics as being "related to each other in so far as the adult education of the parent is an important factor in preschool education" (UIE 1953, p. 3). In retrospect, the election of the adult educator Johannes Novrup as chairperson of the Board seems to have directed the future orientation of the institute. But for many years UIE's programme was rather eclectic.

\section{Comparative education and international understanding in the Cold War: 1952-1965}

The title of UIE's first seminar was indicative: "Adult education as a means of developing and strengthening social and political responsibility" - a theme which was to stay at the heart of the institute's work until the present day. The seminar was attended by 38 participants from 15 countries, mostly from Western Europe. A handful of delegates came from the United States of America or were Americans working in Germany; one participant represented the Ministry of Education of India (Jessup 1953). A lot of hope was placed on international cooperation through multilateral organisations at that time, "and the mixture of people of differing languages, colours and nationalities was still an exciting novelty" (Knoll 2002, p. 14). The institute aroused worldwide interest, and its first director Walther Merck, during a visit of the Sub-Committee of the UNESCO Executive Board in September 1952, mentioned that the UIE was "at times overwhelmed by the number of visitors

\footnotetext{
${ }^{9}$ The Governing Board had appointed Walther Merck from the University of Hamburg, the first professor for comparative education in Germany, as director of the new institute, but the Hamburg government refused to release him from his duties, lobbying for Hamburg as host city of the institute. Finally the Board members took votes, which settled the matter in favour of Hamburg (UNESCO Institut für Erziehung [sic] 1951). The official birthday of the Institute was 23 February 1952, the date when the foundation was registered (Braun, c. 1990).

${ }^{10}$ Using the current day's [24 April 2013] exchange rate, this amount corresponds to approximately USD 502,000 .
} 
from foreign countries" (UIE 1952b) who travelled to the institute, which was like an enclave of internationalism, located in the "old patrician house" (Alenfeld 2002, p. 10) at Feldbrunnenstrasse $70 .^{11}$

During those years, marked by the Cold War, an important function of the institute was to provide a bridge to the East European countries. Given its location in West Germany and its neutrality as a UNESCO institute, the UIE was a place where researchers from the East and the West could meet, something quite unusual at the time (Husén 1997, p. 3). The participants of the meetings were impressed by the "surprising level of accordance" among the representatives of countries from both sides of the Iron Curtain (Badische Neueste Nachrichten 1967). The first participant from the Soviet Union took part in a seminar organised by the institute in 1956 (Elfert 2002, p. 38). Between 1959 and 1998, the Soviet Union, and then Russia, was permanently represented on the Governing Board, joined by a member from Poland between 1974 and $19811^{12}$

In the first decades of its existence, the work of UIE reflects its ambition to cover a range of issues that were considered relevant for social renewal: early childhood education, adult education, school reform and teacher training and the promotion of international cooperation among European teachers, as well as comparative studies, for example on "leisure education" (UIE 1962a) and "parent education" (Stern 1960). In those early years there was quite a high level of collaboration with UIE's sister institutes, as envisaged by UIE's founders. The UNESCO Institute for Social Sciences had been established in Cologne, and the UNESCO Youth Institute in Gauting near Munich. Both carried out research in their respective areas and organised meetings, sometimes in collaboration with UNESCO headquarters in Paris. The three sister institutes held joint seminars, and the chairmen of the three Governing Boards met up on a regular basis (UNESCO 1958, p. 90). The second of the series of "Education for International Understanding" seminars for young teachers was held at the Youth Institute in Gauting in 1956 (Gillett 1957). These seminars were organised between 1955 and 1966 by UIE in cooperation with national UNESCO Commissions. However, the other institutes did not succeed in securing long-term funding and support. The Institute for Social Sciences remained active only until 1960, the Institute for Youth until $1965 .^{13}$

\footnotetext{
11 In 1978 the UIE moved down the road to Feldbrunnenstrasse 58, the former villa of Albert Ballin (1857-1918), one of the founders and the General Director of the world's biggest translatlantic shipping company in his day, the Hamburg America Line (HAPAG). The Free and Hanseatic City of Hamburg still provides the institute with its premises in this protected building today.

12 The International Review of Education (IRE), edited by UIE, regularly published articles on the Soviet Union and Eastern Europe, written by local or foreign authors. The first article by an author from the Soviet Union was published in 1957 (Smirnov 1957). In the 1950s and 1960s the articles were exclusively on school education. In 1970 an entire issue [IRE 16(3)] was dedicated to a broader range of educational matters in Eastern European countries. During the 1970s the first articles appeared on lifelong education in Eastern European countries - the first paper on this matter by an author from the Soviet Union was published in 1977 (Darinskij 1977).

13 The Institute for Social Sciences was absorbed by the Sociological Institute of the University of Cologne. The international tasks of the Youth Institute were taken over by UNESCO headquarters in Paris (Hausmann, c. 1979, p. 51).
} 
In 1955, the first issue of the relaunched International Review of Education (IRE) appeared. The journal, formerly entitled International Education Review, had been founded in 1931 by the German educationist Friedrich Schneider, as a forum for the then new discipline of international comparative education. After a period of appropriation by the Nazi regime and a short period of resurrection under its original editor, the editorship of the journal was assumed by UIE. Friedrich Schneider remained involved as member of the journal's international Editorial Board as well as UIE's Governing Board between 1951 and $1965 .{ }^{14}$ The journal is still edited by the institute today, reflecting international educational debates across all world regions and fields of education across time.

In the late 1950s, UIE became the cradle of the first international comparative school assessment studies. Under the institute's second director, Alv Gunnar Langeland (who succeeded the German Walther Merck in 1955; see Table 1), regular seminars on school issues were held at UIE, which assembled a group of European and North American educational researchers. The initiative for these meetings was taken by William Wall, a staff member of UNESCO in Paris who worked closely with the Assistant Director of Education, Lionel Elvin. The group decided to jointly carry out an empirical cross-country comparative pilot study, which was sponsored by the government of the United States of America. UIE had a coordinating role - the national studies relied on the work carried out by the 12 national research centres involved. The first study was published by UIE in 1962 (UIE 1962b).

Encouraged by the success of the initiative which showed that it was possible to carry out standardised testing of students' levels of educational achievement in different countries, the group embarked on a full-scale study of mathematics, the "First International Mathematics Study" (FIMS) (Husén 1967). ${ }^{15}$ UIE provided a staff member, Neville Postlethwaite, as coordinator of the group, which constituted itself as the "International Association for the Evaluation of Educational Achievement" (IEA). At the time of the next project, the so-called "Six Subject Survey", the staff of the project had grown so large that it could no longer be accommodated by UIE and subsequently moved to Stockholm in 1969 (De Landsheere 1997; Husén 1981, 1997). Over the years, the IEA has developed into a professional organisation with 70 members. Up to today, it has conducted some 30 comparative research studies. Gilbert de Landsheere (1997, p. 3) reflects about the cooperation between UIE and the IEA: "If things had developed differently, it is most likely that IEA could have become a sort of UNESCO Agency for empirical educational research and evaluation ... At the time, there was not sufficient general awareness [by the UNESCO member states] of the importance of monitoring the standards of education." It should be noted that the field of international comparative surveys has been dominated, since the 1990s, by the Organisation for Economic Co-operation and Development (OECD).

\footnotetext{
${ }^{14}$ For more information about the history of the IRE, see the articles by Christopher McIntosh (2002) and Ravindra H. Dave (1984). A historical survey of the educational debates reflected in the IRE can be found in Tuijnman and Boström (2002).

15 For more information about this study see Postlethwaite (1969).
} 


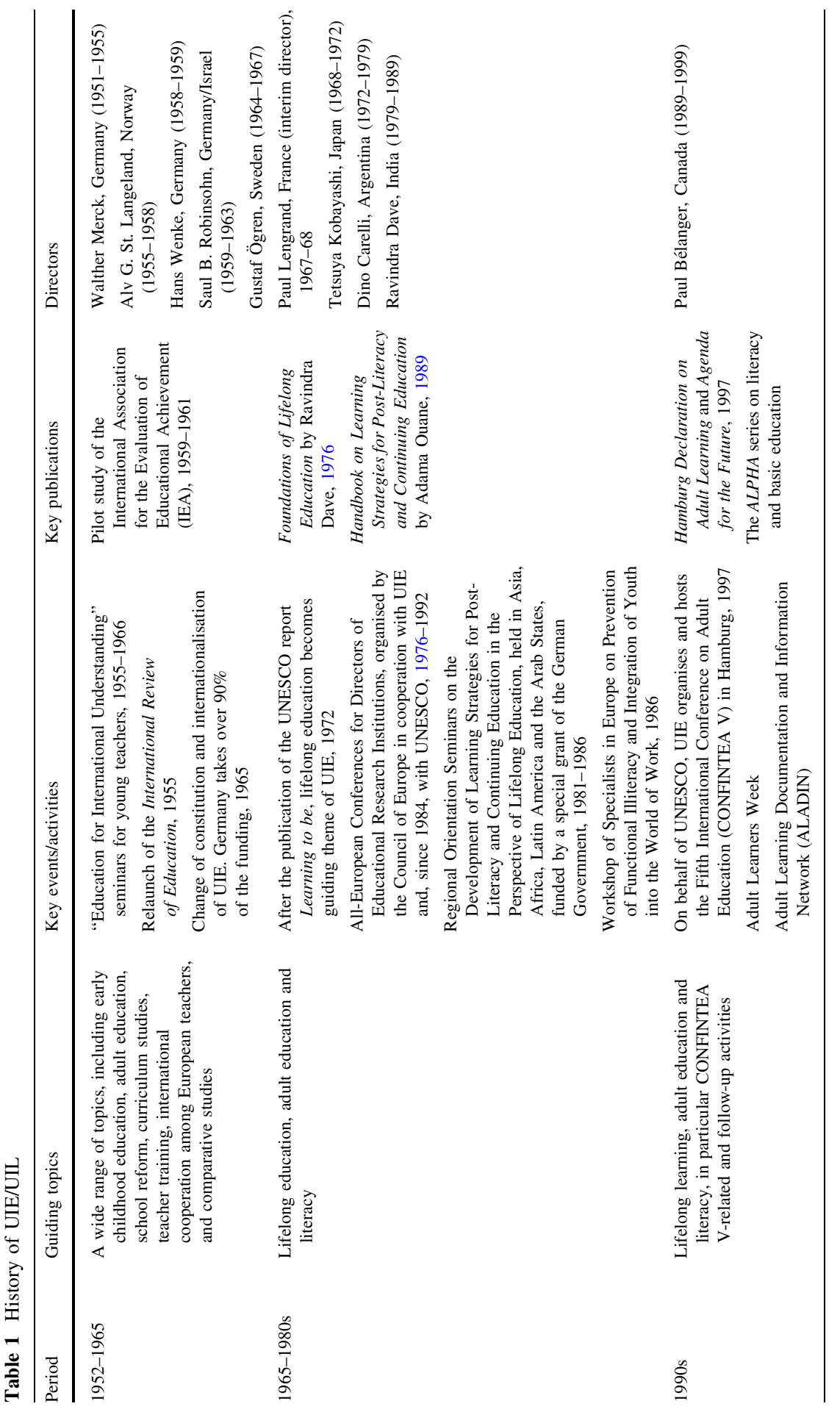




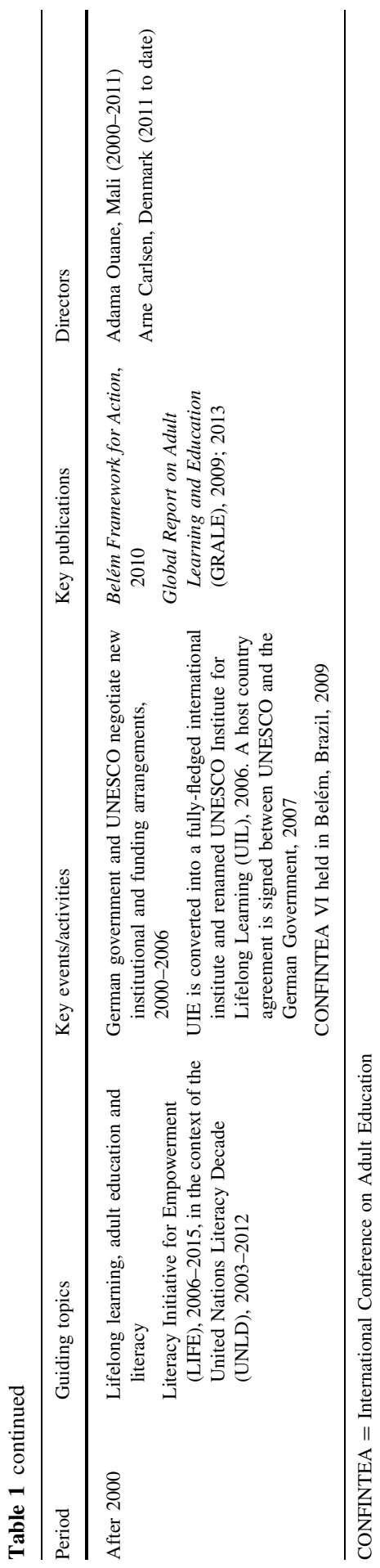


Thus during the early years of the UIE, marked by "an astonishing faith in education" (Priscott 1976, p. 311), the institute gained importance as a meeting place where educators could exchange ideas and build international networks, on both sides of the Iron Curtain. Moreover, the institute guided innovative research such as the first international comparative school assessment studies. The year 1965 marked a turning point in the history of UIE, which will be discussed in the next section.

\section{5 until the end of the 1980s: Lifelong education and literacy}

In the early stage of the institute's life, its main sources of income were contributions from member states and UNESCO funding. UNESCO funding was continually reduced and ceased in 1968, forcing the institute to turn to its host country for financial support. The German government was interested in maintaining the institute because of its function as East-West mediator (Hausmann 1979, p. 7). Negotiations between UNESCO and Germany led to the agreement that the Federal Government would take over 90 per cent of UIE's budget between 1966 and 1975 (ibid.), limiting the UNESCO contribution to the salary of the institute's director, whose position was upgraded.

Despite the increase in German funding, German influence in the Governing Board decreased. Due to the process of decolonisation, the geographical focus of the institute, which had been so far in Western countries and Germany, started moving towards the global South. These developments were reflected by a change of the institute's constitution in 1965. UIE's Governing Board was to include more representatives of all world regions. The new constitution maintained the mandate of "international understanding" and the institute's responsibility to carry out work in Germany. At the same time, it introduced a greater alignment with UNESCO, emphasised the institute's international scope and established the developing countries as a new regional focus (Ögren 1966).

1965 was a critical year in the history of the institute. Gustaf Ögren from Sweden who succeeded the German-Jewish émigré Saul Robinsohn as director of UIE, had a hard time paying the bills as the institute was left with no income in the transition phase between the cessation of the UNESCO funds and the arrival of the German funds (Kölner Stadtanzeiger, 1966). Also, the changes in the funding arrangement and the constitution of UIE sparked an identity-finding process. In 1971, the Governing Board found that "there was no indication of the fields into which the Institute should move" and established an "Advisory Committee on Long Range Planning ... to develop a coherent programme ... and select one theme" (Hausmann 1979, p. 9). Two topics emerged from the discussions of the committee: "Education extending throughout adult life" and "curriculum problems" (ibid.).

The publication of a UNESCO education report in 1972 made the pendulum swing in the direction of the first topic. That report was UNESCO's response to what many perceived as a "world educational crisis" (Coombs 1968). The rise of educational needs in newly independent countries, the expanding education systems in industrialised countries and increasing globalisation and spread of technology 
were major challenges at the time. René Maheu, UNESCO's then Director-General, made sure that UNESCO would have a voice in the debates over education by calling a high-level education commission, chaired by Edgar Faure, a former French Minister of Education and Minister of Social Affairs. The commission presented the report Learning to be in 1972 (Faure et al. 1972). It presented lifelong education as "the master concept in the years to come for both developed and developing countries" (ibid., p. 182), stressing the role of education for democratisation, scientific development and equality in the era of the "scientific-technological revolution" (ibid., p. xxii). In the following years, UIE brought together a team of scholars, led by Ravindra Dave ${ }^{16}$ in order to explore (1) the conceptual foundations and theoretical framework of lifelong education from an interdisciplinary perspective (Dave 1976) and (2) the operational aspects of a system of lifelong education (Cropley 1980). The institute published nine monographs, carried out several projects and organised numerous seminars on the topic.

Lifelong education widened the scope of UNESCO's definition of education. It went beyond the categories of "fundamental" and "basic" education, introducing a holistic and encompassing idea of education, which is not restricted to a certain (age) group or institution. In its origins, lifelong education resembled the humanist vision of UIE's founders: "[Lifelong education] is a comprehensive and unifying idea which includes formal, non-formal and informal learning for acquiring and enhancing enlightenment so as to attain the fullest possible development in different stages and domains of life" (Dave 1976, p. 34). The concept was tied to the belief in democracy as a social and political system built on "each man's right to realize his own potential and to share in the building of his own future" (Faure et al. 1972, p. vi).

Entering the field of lifelong education gave the institute a clear mandate and profile. At UIE's Standing Committee meeting in Paris in November 1973, the then Assistant Director-General Amadou-Mahtar M'Bow "stressed that past difficulties in clearly distinguishing between the work of the Institute and that of the other Unesco-related organisations had been overcome by the new orientation of the UIE in the area of lifelong education" (Hausmann, c. 1979, p. 13). The existence of the International Institute for Educational Planning (IIEP) in Paris, which had been created by UNESCO in 1963 in order to support the new countries of the global South in developing their education systems, and the International Bureau of Education (IBE) in Geneva, which was integrated into UNESCO in 1968, called for a clear definition of roles. This brought about some conflicts and confusions. Both IBE and UIE felt they owned comparative education. In 1970 the roles of the three educational UNESCO institutes were defined as follows: The IIEP was to deal with "training and research in educational planning and administration"; the IBE with "public authorities", and UIE with "academic institutions of educational research" (Hausmann 1979, p. 8). For the first time UIE's activities were included in UNESCO's programme for 1975-1976, agreed at the 18th General Conference. Surprisingly, adult education was associated with the IBE, which was supposed to "undertake comparative studies" and "educational research" (UNESCO 1974, p. 29), both fields of work of UIE. The purpose of UIE is stated as "promoting

${ }^{16}$ Dave, UIE's future director, joined UIE as Technical Director in 1972. 
interdisciplinary and developmental research on lifelong education, with special reference to school curricula, as a contribution to the renovation of education systems" (ibid., p. 24). In fact, school curricula remained on UIE's working agenda until the early 1980s.

The 1970s were marked by conceptual work aiming to clarify "the ideas of lifelong education and its implications for educational practice" (Hawes 1974) and the strengthening of educational research. Another key activity were the "European Seminars on Learning and the Educational Process" (SOLEP), a series of training workshops for educational researchers, started under UIE's sixth director Tetsuya Kobayashi in 1968, which continued until 1972. After two seminars held in Sweden and France, the third seminar was organised in Thailand for Asian researchers, demonstrating UIE's widening geographical scope during those years. Later, under Kobayashi's successor Dino Carelli, an opportunity arose for UIE to cooperate in the All-European Conferences for Directors of Educational Research Institutions, initiated by the Council of Europe, which sought cooperation with UIE and UNESCO as a means of establishing contacts with countries in Eastern Europe. These meetings were held between 1976 and 1992 and aimed to promote and foster research networks in education and to provide Ministries of Education with research findings that could impact their policy decisions.

In 1979 Ravindra Dave returned to UIE as director, after having spent the years 1976-1979 at the IIEP in Paris. Interested in getting the institute more involved in developing countries, he launched UIE's activities in literacy, a field which had been at the heart of UNESCO's work since its beginnings (Jones 1990; Limage 1999). The early 1980s were a time when many developing countries launched mass programmes of adult literacy, complementary to the universalisation of primary education for children. These mass initiatives focused on teaching adult learners to read and write, without taking into consideration that they would lose their newly obtained literacy skills if these were not sustained and put to use on a regular basis. UIE promoted an approach to literacy as a "continuum" (UIE 2000), a lifelong process. With the support of the Federal Republic of Germany and the German Commission for UNESCO, the institute implemented a post-literacy and continuing education programme as part of its research in lifelong education (Dave et al. 1989a). It was the first project that UIE carried out on its own initiative in the developing world. Case studies were undertaken in several countries, and researchand policy-oriented seminars were held for practitioners and programme planners in all world regions. The project allowed the institute's documentation centre to build up a collection of literacy materials in 160 languages from more than 120 countries. It resulted in a series of influential publications and established UIE's reputation in developing countries. According to the lead researcher Adama Ouane (1989), the findings of the project were disseminated to some 300 key education practitioners and planners at national level in about 100 developing countries.

At the same time, UIE was at the forefront of the debate on functional illiteracy in industrialised countries, which emerged in the 1980s. The functional or "pluridimensional" (Jones 1990, p. 57) approach to literacy in developing countries (Jones 1990, Ouane 1992) was applied to industrialised countries, which called "for a different strategy and methodological approach compared to the situation of "mass 
illiteracy"” (Dave et al. 1989b, p. 405). In 1986, the institute started a research project on functional illiteracy. A workshop was held at UIE, which had been preceded by a series of case studies on post-literacy and continuing education in ten industrialised countries (UNESCO 1986). The initiative derived from the UNESCO General Conference in 1985 and was "outsourced" to UIE and funded by UNESCO. When in 1989 the Canadian Paul Bélanger succeeded Ravindra Dave as director of UIE, he intensified the work on literacy research in industrialised countries and strengthened collaborations with the OECD and the European Union (UIE 1991). Moreover, International Literacy Year in 1990 created a momentum for literacy. The meetings held at UIE in the early 1990s were concerned with the dimensions of functional illiteracy, policy-oriented research and "evidence of social and economic progress from literacy" (UIE 1992a, p. 4). In those years, UIE published the ALPHA series, covering international research in literacy and basic education, with a focus on industrialised countries. ALPHA mirrored the radical and critical traditions in UIE with its "questioning of the social construct of illiteracy and its functions of discrimination and social control" (Hautecoeur 2001, p. 415).

It was certainly crucial for the survival of the institute that it managed to secure its funding into the third decade of its existence and that it moved away from its focus on Germany and Europe towards the developing countries. The continued funding provided by the German government allowed the institute to develop its expertise in lifelong education and literacy during the 1970s and 1980s. UIE built up the Literacy Exchange Network for developing and industrialised countries, in which by 1995 1,400 members from 141 countries actively participated (UIE 1995). But it also organised important events in the field of adult education. The "European Conference on Motivation for Adult Education", held in Hamburg in 1983, is noteworthy in this regard as it was the European preparatory meeting for the Fourth International Conference on Adult Education (CONFINTEA IV). ${ }^{17}$ In the decade to follow, CONFINTEA would take up a large role in UIE's life.

\section{The 1990s: CONFINTEA V and adult education}

The 1990s were "years of paradoxes ... the worst of times, and the best of times" (Bhola 1998, p. 493), when both the good and the bad faces of globalisation came to the fore. In terms of educational policy, these years were marked by the tension between the UN's and UNESCO's renewed interest in human rights, manifested by "summits of idealism" (Bhola 1998, p. 493), ${ }^{18}$ and a neoliberal turn in organisations such as the World Bank and the OECD, stressing the economistic and utilitarian agenda of education (Jones and Coleman 2005; Rubenson 2006). The Education for All (EFA) initiative was launched in Jomtien in 1990 as a UN-wide drive to universalise education, allying several UN organisations, including UNESCO, the

\footnotetext{
17 CONFINTEA is an intergovernmental conference of UNESCO, held every 12 years since 1949. For accounts of the history of CONFINTEA, see Knoll (2007) and Kidd (1974).

18 These include the World Conference on Education for All in Jomtien (1990); the United Nations Conference on Environment and Development in Rio de Janeiro (1992); the World Conference on Human Rights in Vienna (1993); and the Fourth World Conference on Women in Beijing (1995).
} 
United Nations Children's Fund (UNICEF) and the World Bank. EFA was reconfirmed at the World Education Forum in Dakar in 2000 when the coordination for the EFA process was given to UNESCO. Despite the "balanced attention to the education of children, youth and adults" originally foreseen in Jomtien (Bhola 1998, p. 492), UNICEF and the World Bank focused on the expansion of primary education, and adult education was neglected (Bhola 1998). As Rosa María Torres (2011, p. 43) argues, the main organising concept of EFA was "basic education", not lifelong learning. UIE's role in the context of EFA was to lobby for integration of a lifelong learning perspective and of adult education into national EFA plans. This was the purpose of numerous policy dialogues organised by UIE in all world regions (e.g. Medel-Añonuevo 2001, 2006; Singh 2002).

The Fifth International Conference on Adult Education (CONFINTEA V), scheduled for 1997, was another international conference at a time when UNESCO was being criticised for its culture of big events. CONFINTEA IV, held in Paris in 1985, had not left a lasting impression on the adult education community (Knoll 2007). Enthusiasm for CONFINTEA V was therefore low, and Paul Bélanger seized the opportunity to lobby for its transfer to UIE. That he succeeded is owed to the goodwill of a group of people in key positions who wished to strengthen the institute by raising its profile and that of adult education: Peter Fischer-Appelt, Chair of UIE's Governing Board from 1992 to $1996,{ }^{19}$ tirelessly lobbied for the institute to become the organiser of CONFINTEA V; Colin Power, the Assistant DirectorGeneral (ADG) for Education, was a supporter of UIE; and Federico Mayor, the Director-General of UNESCO, mobilised support for the conference among the United Nations agencies. ${ }^{20}$ The German authorities also played their part. After the period under Ravindra Dave's directorship when UIE's work had focused on developing countries, they were keen for UIE to gain more relevance in industrialised countries.

CONFINTEA $\mathrm{V}$ is considered a milestone in the history of the CONFINTEA conferences mainly for three reasons. First, the conference broadened the perspective of adult education by showing its diverse and multi-sectoral nature. Its ten themes included "traditional" themes (such as literacy and basic education) and "non-traditional" themes (such as health, environment, media and culture) and put a strong emphasis on the perspective of women and minority groups. The conference mobilised a wide range of actors, resulting in a much larger number of participants than had been expected. ${ }^{21}$ The conference marked the shift from adult education to adult learning, stressing the individual process of learning over the institutional and provisionary aspect. This shift was influenced by the report of the UNESCO Commission on Education for the Twenty-first Century, chaired by Jacques Delors, Learning. The Treasure Within, published in 1996 (Delors 1996). The Delors report followed the Faure report in its humanist character, reflecting

\footnotetext{
19 Prior to this, Peter Fischer-Appelt had been President of the University of Hamburg from 1970 to 1991.

20 Paul Bélanger (1998) describes a conversation with Federico Mayor about CONFINTEA V.

21 Joachim Knoll (2007, p. 34) indicates that the number of participants was "well over 1500".
} 
about the role of education and learning for human and social development in the face of a rapidly changing and increasingly diverse world by putting the emphasis on the ability of human beings to learn. Whereas some have criticised the report for not paying enough attention to adult education (Bhola 1998) or for its "high-flown rhetoric and platitudes" (Watson 1999, p. 14), others stress the impact it had on educational debates (Lee and Friedrich 2011). The second feature of CONFINTEA $\mathrm{V}$ was the strong involvement of non-governmental organisations and civil society in the conference and its preparation, which was a novelty (Bélanger 1998; Knoll 2007). Third, the conference was positively assessed because of the quality of its outcome documents, the Hamburg Declaration on Adult Learning and The Agenda for the Future (UIE 1997), which had some impact on the field of adult education around the world.

Taking over the responsibility for CONFINTEA $\mathrm{V}$ gave the institute a new work agenda and raison d'être. It implied that a great deal of responsibility for adult and continuing education had been transferred from UNESCO headquarters to UIE (Limage 1999, p. 87). Several initiatives came out of CONFINTEA V, which were coordinated by the institute, such as the international network of Adult Learners Week events and a global network of adult learning documentation and information centres (ALADIN).

\section{The new millennium}

The change of its legal status at the beginning of the new millennium "marked a new era in the Institute's history" (Matsuura 2007). In 2000, the German government announced the progressive phasing out of its institutional funding over five years. ${ }^{22}$ Since 1966 , when the German government assumed responsibility for 90 per cent of UIE's regular expenses, the German institutional funding had grown from USD 360.000 (Braun, c. 1990) to USD 950.000 in 2000 (UIE 2000, p. 22). ${ }^{23}$

This funding crisis at the beginning of the term of Paul Bélanger's successor Adama Ouane threatened the survival of the institute. Behind closed doors, German and UNESCO officials discussed the possibility of merging the institute with the International Centre for Technical and Vocational Education and Training (UNEVOC), which had been established in Bonn, Germany in 2002, much to the displeasure of the City of Hamburg, which was eager to keep the institute. Finally, the strenuous negotiations between UNESCO, the German government and the Hamburg authorities took a positive turn, facilitated by a resolution adopted in 2001 by the General Conference to give the institute an international status. In order to save the institute, UNESCO assumed greater financial responsibility by committing to fund seven staff positions. However, funding for all activities and the rest of the

\footnotetext{
22 This move was officially attributed to a decision by the German Federal Court of Auditors who considered the financial support to UIE a "double funding", since Germany was already paying membership dues to UNESCO.

23 Today, UIL's budget is at about USD 3,700,000 (UIL 2013).
} 
personnel had to be procured from other sources, a difficult task in the highly competitive environment of project-related funding.

In 2006, UIE was legally closed and succeeded by a fully-fledged international institute, provided with a host country agreement between the German Foreign Office and UNESCO which was signed in 2007. The new institution was named UNESCO Institute for Lifelong Learning (UIL), which was seen to better reflect the work of the institute. ${ }^{24}$

The statutes of the new UIL defined "literacy, non-formal education, and adult and lifelong learning ... with special emphasis on least developed countries" as the working areas of the institute (UNESCO 2003, p. 35). Under the directorship of Adama Ouane the institute re-intensified work in developing countries, especially in Africa, as well as South-South cooperation, and emphasised the importance of mother-tongue education and literate environments for literacy.

The change of name and legal status brought about a much closer alignment of UIL with the administrative rules and regulations of UNESCO headquarters and a tighter integration of its work into UNESCO's programme. An example of this is UIL's involvement in UNESCO's literacy work since the launching of the United Nations Literacy Decade (UNLD) in 2003. In the course of a major restructuring of the UNESCO Education Sector in 2006 a substantial part of UNESCO's literacy work was transferred to UIL, including the Literacy Initiative for Empowerment (LIFE), launched in 2006 as an effort to accelerate literacy in those 35 countries worldwide that face the biggest literacy challenges (Limage 2007). The transfer of greater responsibilities to the institute, which now was not only the main "clearinghouse for lifelong learning" 25 but also in charge of two major UNESCO initiatives - LIFE and CONFINTEA VI -, was in line with a new strategy for the UNESCO Institutes, which represented the decentralisation and streamlining principles followed by UNESCO's management at the time, aiming at greater accountability for the institutes and closer alignment of their work with the UNESCO programme (UNESCO 2001). Currently there are indications that UNESCO is reverting to greater centralisation, and efforts are being made to revitalise the programme area of literacy within the organisation, resulting in a recent retransfer of LIFE to Paris.

The Belém Framework of Action, the outcome document of CONFINTEA VI, held in 2009 in Belém, Brazil, again organised by UNESCO's Hamburg institute, mandates the institute to coordinate, in partnership with the UNESCO Institute for Statistics (UIS), a "monitoring process" (UIL 2010, p. 9) and to produce on a regular basis the Global Report on Adult Learning and Education (GRALE), the

\footnotetext{
24 The change of name had been recommended in the course of an external evaluation of the institute carried out in 2005, "in order to closer align it with its objectives and activities" (Aamondt and Kyvik 2006, p. 26) and was later supported by the Governing Board. More specifically, the evaluators argued: "The deliberate choice made to concentrate UIE's activities on out-of-school modes of learning and targeting learners other than school children, namely out-of-school children, young people and adults, is not reflected in the name of the institute" (ibid.). The German name - UNESCO-Institut für Pädagogik "has long been considered inappropriate and obsolete." (UNESCO 2006, p. 1).

25 Foreword by the Assistant Director-General for Education, Qian Tang, in the UIL Annual Report 2011 (UIL 2012).
} 
first edition of which was published prior to CONFINTEA VI (UIL 2009). Another mandate given to the institute is that of revisiting and updating the Recommendation on the Development of Adult Education adopted in Nairobi in 1976 (UNESCO 1976), the key standard-setting document produced by UNESCO on adult education so far. Apart from the conceptual and empirical work on adult education carried out in the context of CONFINTEA, literacy and lifelong learning still constitute the main pillars of UIL's activities today, under its current director Arne Carlsen.

\section{Conclusion}

One interesting question is: why has the institute survived "among the myriad of competing institutions in the often troubled arena of international cooperation" (Ouane 2002, p. 6)? One of the reasons may lie in its capacity to adapt to the changing world order and to be at the forefront of educational trends. Founded as one of three institutes with the mandate of promoting international understanding and supporting social renewal in war-torn Germany and Europe, UIE developed into an international organisation that shaped global educational research and policy development in the 60 years of its existence. Starting off with comparative education and the first empirical studies, UIE exercised a great deal of intellectual influence through its conceptual work on lifelong education in the 1970s.

Throughout its history, its regional focus shifted, but the tension between the institute's "international" and "Western" mandates was never dissolved. Located in Germany under the influence of Western countries, it assumed the role of a mediator to the countries behind the Iron Curtain. When a large number of newly independent countries in the global South joined UNESCO and the organisation shifted from "intellectual matters to development" (Hoggart 1978, p. 66), UIE entered the field of capacity-building and its regional focus moved more and more to developing countries and finally to "least developed countries", although much of its work always remained global in scope. The meetings it organised, which many consider the institute's most important role (Kobayashi 2002; Gal 1962), provided a space for exchange for Eastern/Western European countries as well as for countries in the global North/South. These meetings could be held in a less formal environment than at UNESCO's headquarters in Paris, since participants were invited in their capacity as experts, not as official representatives of their countries.

CONFINTEA V brought about a new dimension of global policy formulation and standard-setting, complemented by empirical and comparative research. The institute played a major role in shaping lifelong learning as a global educational paradigm. It was instrumental in the shift from education to learning and in shaping the concept of literacy as a "continuum". Over the decades, it moved away from formal education and highly contributed to the understanding of non-formal and informal learning. Since much of UIE's work was conceptual in nature, it is difficult to establish causal relationships, but there is evidence that some countries' policies, especially in Asia and Africa have been directly influenced by UIE's work (see UIE 2004, pp. 32-33; Walters et al. 2012, chapter 6). 
Despite UIE's capacity to change, there was a certain continuity in its educational philosophy and ideology. While taking some pragmatic "turns" in adapting to the dominant discourses and trends, the institute has always stayed situated within the idealist tradition, shaped by the vision of the institute's founders, who took the individual human being as point of departure. All UIE's programmes have stressed the human rights-based and emancipatory character of adult education and have been influenced by thinkers such as Paulo Freire, ${ }^{26}$ Gottfried Hausmann, ${ }^{27}$ Paul Lengrand, ${ }^{28}$ and Bogdan Suchodolski. ${ }^{29}$ UNESCO and UIE have represented the humanist "first generation of lifelong learning" (Rubenson 1999), against the competing economistic and utilitarian approach to education put forward by other international organisations such as the OECD (Rubenson 2006) and the World Bank (Jones and Coleman 2005; Tomasevski 2005). With this counter-mainstream position the institute earned widespread sympathy across the adult education community, especially in developing countries. Starting with its post-literacy work, UIE built up a strong reputation in countries of the global South. Many of the letters of support that the institute received during the years of crisis after the decision of the German government to phase out its funding came from non-governmental organisations and academic institutions in the global South and stressed the importance of UIE's focus on the developing countries as well as on disadvantaged and marginalised populations. ${ }^{30}$

Another factor that may have played out to UIE's advantage was its awkward legal status as a German foundation. Neither UNESCO nor Germany felt fully responsible for it. On the one hand, this constituted a problem for the institute since it always had to struggle for greater recognition. On the other hand, this situation allowed for a certain autonomy and life of its own.

Today, the UIL is connected much closer to UNESCO headquarters than ever before. "Results-based accountability" (UNESCO 2012, p. 7) structures are making it difficult for UIL to keep up its autonomy. There are indications that UNESCO will respond to its current financial crisis ${ }^{31}$ with a trend to centralising activities, resulting in a reduction of the support it provides to the institutes. Given increasing competition in the arena of development cooperation and a much tougher struggle

\footnotetext{
${ }^{26}$ The renowned Brazilian educator, philosopher, and influential theorist of critical pedagogy Paulo Freire visited the institute in 1992, to attend its 40th anniversary celebrations. His speech is reproduced in Freire (1992; UIE 1992b). He had been invited to CONFINTEA V but died shortly before the conference.

27 Gottfried Hausmann was the successor of Walther Merck as Professor of Comparative Education at the University of Hamburg. After he retired in 1974, he continued to be active as a member of the German UNESCO Commission and as an adviser to UIE. A room in the premises of the institute is named after him, the "Hausmann room", which has a number of desks for interns and international fellows to work at.

28 Paul Lengrand was one of the pioneers of UNESCO and of lifelong learning. He started working at UNESCO headquarters in Paris in 1948. In 1962, he became head of the adult education section and later head of the Division of Curriculum and Structures of Lifelong Education, created in 1973. In 1967/68 he served as interim director of UIE.

29 Bogdan Suchodolski, a Polish humanist, was one of the founding members of UNESCO and member of UIE's Governing Board from 1974 to 1981.

30 See "Views of UIE" (Elfert 2002, pp. 75-77).

31 This was caused by the United States withholding their membership dues after the General Conference admitted Palestine as full member to UNESCO on 31 October 2011.
} 
for funding, occupying a niche today is certainly more difficult than during the periods in which the institute benefited from some financial stability.

The challenge for UIL today is to adapt to a new situation yet again. UIL has built a distinctive area of competence in the competitive arena of educational multilateralism. However, it remains to be seen how the institute will keep up its distinctive profile in the fast-moving world of budget constraints and shifting priorities.

Acknowledgments The paper has greatly benefited from the support of Hans-Wolf Rissom who graciously shared his vast knowledge of the history of UNESCO and the UIE. I would also like to thank the IRE's Executive Editor Stephen Roche for all of his support and his comments on earlier drafts of the paper. I am grateful to Paul Bélanger for providing his insights on developments related to CONFINTEA. Last but not least, I wish to thank Maya Kiesselbach for her excellent editing.

\section{References}

Aamondt, P. O., \& Kyvik, S. (2006). Evaluation of the UNESCO Institute for Education. IOS/EVS/PI/39/ REV UNESCO Internal Oversight Service. Evaluation Section. Paris: UNESCO. Accessed 24 April, 2013, from http://unesdoc.unesco.org/images/0014/001449/144946E.pdf.

Alenfeld, I. (2002). Old affections never fade, or what I love about UIE. In M. Elfert (Ed.), Towards an open learning world (pp. 10-12). Hamburg: UNESCO Institute for Education.

Badische Neueste Nachrichten. (1967). 5 Dezember. Allgemeinbildung in Ost und West. Tagung des Unesco-Instituts in Hamburg.

Bélanger, P. (1998). The preparation and the organization of CONFINTEA V - Concepts and strategies. In J. Knoll (Ed.), Internationales Jahrbuch der Erwachsenenbildung [International yearbook of adult education] (Vol. 26). Köln: Böhlau Verlag.

Bhola, H. S. (1998). World trends and issues in adult education on the eve of the twenty-first century. International Review of Education, 44(5-6), 485-506.

Braun, H. [c. 1990]. A brief history of the UNESCO Institute for Education. Unpublished paper, UIL Archives, Hamburg.

Coombs, P. H. (1968). The world educational crisis: A systems analysis. Oxford: Oxford University Press.

Cropley, A. J. (Ed.). (1980). Towards a system of lifelong education: Some practical considerations. Hamburg/Oxford: UNESCO Institute for Education/Pergamon Press.

Darinskij, A. V. (1977). Lebenslanges Lernen in der UdSSR. International Review of Education, 23(3), 287-303.

Dave, R. H. (Ed.). (1976). Foundations of lifelong education. Hamburg/Oxford: UNESCO Institute for Education/Pergamon Press.

Dave, R. H. (1984). Introduction to the thirtieth volume of the IRE. International Review of Education, 30(1), 3-9.

Dave, R. H., Ouane, A., \& Sutton, P. (1989a). Editorial introduction. International Review of Education, 35(4), 383-387.

Dave, R. H., Ouane, A., \& Sutton, P. (1989b). Issues in post-literacy. International Review of Education, 35(4), 389-408.

De Landsheere, G. (1997). IEA and UNESCO: A history of working co-operation. Paper on the accompanying CD to the UNESCO publication 50 Years of Education. Paris: UNESCO. Accessed April 24, 2013, from http://www.unesco.org/education/pdf/LANDSHEE.PDF.

Delors, J., et al. (1996). Learning: The treasure within. Report to UNESCO of the international commission on education for the twenty-first century. Paris: UNESCO.

Deutsche UNESCO-Kommission (Ed.). (2001). Lernziel Weltoffenheit. Fünfzig Jahre Deutsche Mitarbeit in der UNESCO. Bonn: Deutsche UNESCO-Kommission.

Elfert, M. (Ed.). (2002). Towards an open learning world. Hamburg: UNESCO Institute for Education. Accessed April 24, 2013, from http://www.unesco.org/education/uie/pdf/50yearseng.pdf. 
Faure, E., et al. (1972). Learning to be. The world of education today and tomorrow. Paris: UNESCO/ Harrap.

Freire, P. (1992). The purpose of education. In UIE (UNESCO Institute for Education) (Ed.), The 40th Anniversary of the UNESCO Institute for Education. UIE Reports, 6 (pp. 23-28). Hamburg: UNESCO Institute for Education.

Gal, R. (1962). L'Institut de l'Unesco pour l'Éducation à Hambourg. Dix ans d'activité. International Review of Education, 8(1), 1-12.

Gillett, C. R. E. (1957). International understanding - A seminar for young teachers held at Gauting, near München, 23 July to 4 August 1956. International Review of Education, 3(2), 233-234.

Hausmann, G. (1979). Metamorphosen eines internationalen Instituts. Unpublished paper, UIL Archives, Hamburg.

Hausmann, G. [c. 1979]. Metamorphoses of an international institute. A history of the Unesco Institute for Education. Unpublished paper, UIL Archives, Hamburg.

Hautecoeur, J.-P. (2001). The story of ALPHA-In three parts. International Review of Education, 47(5), 407-426.

Hawes, H. W. R. (1974). Lifelong education, schools and curricula in developing countries. Report of an international seminar. Hamburg, 9-13 December 1974. UIE Monographs 4. Hamburg: UNESCO Institute for Education. Accessed April 24, 2013, from http://unesdoc.unesco.org/images/0001/ 000160/016067eo.pdf.

Hoggart, R. (1978). An idea and its servants. UNESCO from within. New York: Oxford University Press.

Husén, T. (Ed.). (1967). International study of achievements in mathematics. Stockholm: Almqvist \& Wiksell.

Husén, T. (1981). An incurable academic. Memoirs of a professor. Oxford: Pergamon Press.

Husén, T. (1997). Two UNESCO endeavours in education: The Hamburg Institute and the International Institute for Educational Planning. Personal memoirs. Paper on the accompanying $\mathrm{CD}$ to the UNESCO publication 50 Years of Education. Paris: UNESCO. Accessed April 15, 2013, from www.unesco.org/education/pdf/HUSEN_1.PDF.

Jessup, F. W. (1953). Adult education towards social and political responsibility. International conference held from the 8th to the 13th September, 1952. Hamburg: UNESCO Institute for Education. Accessed April 23, 2013, from http://unesdoc.unesco.org/images/0013/001313/ 131344eo.pdf.

Jones, P. W. (1990). UNESCO and the politics of global literacy. Comparative Education Review, 34(1), 41-60.

Jones, P. W., \& Coleman, D. (2005). The United Nations and education. Multilateralism, development and globalisation. London and New York: RoutledgeFalmer.

Kidd, A. R. (1974). Tale of three cities, Elsinore-Montreal-Tokyo. The influence of three UNESCO world conferences upon the development of adult education. Landmarks and New Horizons in Continuing Education Series No. 3. Syracuse: Syracuse University Publications in Continuing Education.

Kölner Stadtanzeiger. (1966). 18. Februar. Direktor musste Geld für Putzfrau pumpen. UNESCO-Institut in Hamburg vorerst gerettet.

Knoll, J. (2002). One world, many cultures. In M. Elfert (Ed.), Towards an open learning world (pp. 13-17). Hamburg: UNESCO Institute for Education.

Knoll, J. (2007). The history of the UNESCO international conferences on adult education-from Helsingör (1949) to Hamburg (1997). Convergence, XL(3-4), 21-41.

Kobayashi, T. (2002). A reminiscence. In M. Elfert (Ed.), Towards an open learning world (pp. 65-66). Hamburg: UNESCO Institute for Education.

Lee, M., \& Friedrich, T. (2011). Continuously reaffirmed, subtly accommodated, obviously missing and fallaciously critiqued: Ideologies in UNESCO's lifelong learning policy. International Journal of Lifelong Education, 30(2), 151-169.

Limage, L. J. (1999). Literacy practices and literacy policies: Where has UNESCO been and where might it be going? International Journal of Educational Development, 19, 75-89.

Limage, L. J. (2007). Organizational challenges to international cooperation for literacy in UNESCO. Comparative Education, 43(3), 451-468.

Matsuura, K. (2007). Letter from UNESCO's Director-General Kö̈chiro Matsuura to Mr Georg Boomgaarden, Secretary of State of the Ministry of Foreign Affairs, Federal Republic of Germany, 13 April. Hamburg: UIL Archives.

McIntosh, C. (2002). Editorial introduction. International Review of Education: A Journal of Many Incarnations, 48(1-2), 1-20. 
Medel-Añonuevo, C. (Ed.). (2001). Integrating lifelong learning perspectives. Hamburg: UNESCO Institute for Education. Accessed April 25, 2013, from http://unesdoc.unesco.org/images/0012/ 001264/126485e.pdf.

Medel-Añonuevo, C. (2006). Operationalizing the policy discourses of lifelong learning: Challenges for Africa. Tunis: Association for the Development of Education in Africa (ADEA). Accessed April 24, 2013, from http://www.adeanet.org/adeaPortal/adea/biennial-2006/doc/document/A5_3_annonuevo_ en.pdf.

Montessori, M. (1992). Speech at the Governing Board of the UNESCO Institute for Education, 1951. In UNESCO Institute for Education (Ed.), The 40th Anniversary of the UNESCO Institute for Education. UIE Reports, 6 (pp. 49-51). Hamburg: UNESCO Institute for Education.

Mundy, K. (2010). "Education for all" and the global governors. In D. D. Avant, M. Finnemore, \& S. K. Sell (Eds.), Who governs the globe? (pp. 333-355). Cambridge: Cambridge University Press.

Ögren, G. (1966). Institutes notes. International Review of Education, 12(3), 388-390.

Ouane, A. (1989). Handbook on learning strategies for post-literacy and continuing education. UIE Studies on Post-literacy and Continuing Education, 7. Hamburg: UNESCO Institute for Education. Accessed April 24, 2013, from http://unesdoc.unesco.org/images/0008/000845/084592eo.pdf.

Ouane, A. (1992). Functional literacy: North-South perspectives. Annals of the American Academy of Political and Social Science, 520, 66-75.

Ouane, A. (2002). Foreword. In M. Elfert (Ed.), Towards an open learning world (pp. 6-7). Hamburg: UNESCO Institute for Education.

Postlethwaite, N. T. (1969). IEA mathematics study. Target populations, sampling and tests. International Review of Education, 15(2), 136-141.

Priscott, L. (1976). The UNESCO Institute for Education, Hamburg: 25 years in the service of educational research. International Review of Education, 22(3), 311-315.

Rubenson, K. (1999). Adult education and training: The poor cousin. An analysis of OECD reviews of national policies for education. Scottish Journal of Adult Education, 5(2), 5-32.

Rubenson, K. (2006). Constructing the lifelong learning paradigm: Competing visions from the OECD and UNESCO. In S. Ellers (Ed.), Milestones in adult education (pp. 63-78). Copenhagen: Danish University Press.

Singh, M. (Ed.). (2002). Institutionalising lifelong learning. Creating conducive environments for adult learning in the Asian context. Hamburg: UNESCO Institute for Education. Accessed April 24, 2013, from http://www.unesco.org/education/uie/pdf/ILLBOOK.pdf.

Skovmand, R. (1962). Johannes Novrup and Danish adult education. International Review of Education, $8(2), 131-139$.

Smirnov, A. A. (1957). Les réussites scolaires et les problèmes de la psychologie. International Review of Education, 3(3), 308-321.

Stern, H. H. (1960). Parent education. An international survey. Studies in Education. Journal of the Institute of Education, University of Hull. Special Monograph. Hull/Hamburg: University of Hull/ UNESCO Institute for Education. Accessed April 24, 2013, from http://unesdoc.unesco.org/ images/0013/001315/131506eo.pdf.

Tomasevski, K. (2005). Has the right to education a future within the United Nations? A behind-thescenes account by the Special Rapporteur on the Right to Education 1998-2004. Human Rights Law Review, 5(2), 205-237.

Torres, R. M. (2011). Lifelong learning: Moving beyond Education for All (EFA). In J. Yang \& R. Valdés-Cotera (Eds.), Conceptual evolution and policy developments in lifelong learning (pp. 40-50). Hamburg: UNESCO Institute for Lifelong Learning. Accessed April 24, 2013, from http://unesdoc.unesco.org/images/0019/001920/192081E.pdf.

Tuijnman, A., \& Boström, A.-K. (2002). Changing notions of lifelong education and lifelong learning. International Review of Education, 48(1-2), 93-110.

UIE (UNESCO Institute for Education) (1951). Erste Tagung des Kuratoriums. Bericht ueber die erste Sitzung in Wiesbaden am 17. Juni 1951 um 9.30 Uhr. Hamburg: UIL Archives.

UIE (UNESCO Institute for Education) (1952a). Constitution. Hamburg: UIL Archives.

UIE (UNESCO Institute for Education) (1952b). In Summary minutes of the second meeting of the Governing Board for Education (held at Hamburg, Feldbrunnenstrasse 70), 23-24 October 1952. Hamburg: UIL Archives.

UIE (UNESCO Institute for Education) (1953). A report on the establishment and development of the Institute, June 1951-June 1953. Nr. GB/15. Hamburg: UIL Archives. 
UIE (UNESCO Institute for Education) (1962a). Evolution of the forms and needs of leisure. A selection of reports contributed by the International Study Group on the Social Sciences of Leisure International Study Group on the Social Sciences of Leisure, during the first stage of an international comparative study, concluded at Portoroz, Yugoslavia, June 1960. Hamburg: UNESCO Institute for Education. Accessed April 15, 2013, from http://unesdoc.unesco.org/ images/0016/001628/162819eo.pdf.

UIE (UNESCO Institute for Education) (1962b). Educational achievements of thirteen-year-olds in twelve countries. International Studies in Education. Hamburg: UNESCO Institute for Education. Accessed April 24, 2013, from http://unesdoc.unesco.org/images/0013/001314/131437eo.pdf.

UIE (UNESCO Institute for Education) (1991). Functional literacy in Eastern and Western Europe. A UIE-UNESCO/EC/OECD-CERI Seminar, 20-22 November 1990. Hamburg: UNESCO Institute for Education. Accessed April 24, 2013, from http://unesdoc.unesco.org/images/0009/000906/0906 61eo.pdf.

UIE (UNESCO Institute for Education) (1992a). The future of literacy and the literacy of the future. Report of the seminar on adult literacy in industrialized countries. UIE, Hamburg, 4-7 December 1991. UIE Reports, 9. Hamburg: UNESCO Institute for Education. Accessed April 24, 2013, from http://unesdoc.unesco.org/images/0009/000951/095163eo.pdf.

UIE (UNESCO Institute for Education) (1992b). The 40th anniversary of the UNESCO Institute for Education. UIE Reports, 6. Hamburg: UNESCO Institute for Education.

UIE (UNESCO Institute for Education) (1995). The UNESCO Institute for Education. Charting lifelong education in transition. UIE Brochure. Hamburg: UNESCO Institute for Education.

UIE (UNESCO Institute for Education) (1997). The Hamburg declaration on adult learning and The agenda for the future. In Fifth international conference on adult education, 14-18 July 1997. Hamburg: UNESCO Institute for Education. Accessed April 24, 2013, from www.unesco.org/ education/uie/confintea/pdf/con5eng.pdf.

UIE (UNESCO Institute for Education) (2000). Annual Report 1999-2000. Accessed April 24, 2013, from http://unesdoc.unesco.org/images/0012/001220/122006e.pdf.

UIE (UNESCO Institute for Education) (2004). Report on the external evaluation of UIE. Hamburg: UNESCO Institute for Education. Accessed April 24, 2013, from http://unesdoc.unesco.org/ images/0015/001502/150285eo.pdf.

UIL (UNESCO Institute for Lifelong Learning) (2009). Global report on adult learning and education. Hamburg: UNESCO Institute for Lifelong Learning. Accessed April 24, 2013, from http://uil. unesco.org/fileadmin/keydocuments/AdultEducation/en/GRALE_en.pdf. Accessed 24 April 2013.

UIL (UNESCO Institute for Lifelong Learning) (2010). Belém Framework for Action Harnessing the power and potential of adult learning and education for a viable future. Hamburg: UNESCO Institute for Lifelong Learning. Accessed April 24, 2013, from http://www.unesco.org/fileadmin/ MULTIMEDIA/INSTITUTES/UIL/confintea/pdf/News/belemframework_trilingual_online.pdf.

UIL (UNESCO Institute of Lifelong Learning) (2012). Annual Report 2011. Accessed April 15, 2013, from http://www.uil.unesco.org/home/.

UIL (UNESCO Institute of Lifelong Learning) (2013). Annual Report 2012. Accessed April 4, 2013, from http://www.uil.unesco.org/home/.

UNESCO (1948a). UNESCO Courier, I(1). Accessed April 15, 2013, from http://unesdoc.unesco.org/ images/0007/000736/073649eo.pdf\#73649.

UNESCO (1948b). UNESCO Courier, I(2). Accessed April 15, 2013, from http://unesdoc.unesco.org/ images/0007/000736/073683eo.pdf\#73683.

UNESCO (1948c). UNESCO Courier, I(10). Accessed April 15, 2013, from http://unesdoc.unesco.org/ images/0007/000738/073867eo.pdf\#73867.

UNESCO (1949a). UNESCO Courier II(5). Accessed April 15, 2013, from http://unesdoc.unesco.org/ images/0007/000739/073993eo.pdf\#73993.

UNESCO (1949b). UNESCO Courier II(10). Accessed April 15, 2013, from http://unesdoc.unesco.org/ images/0007/000741/074130eo.pdf\#74130.

UNESCO (1950a). Activities of UNESCO in Germany. Submitted to the UNESCO Executive Board, 23 X/9. Hamburg: UIL Archives.

UNESCO (1950b). Report of the Director-General on Studies concerning the German refugee problem, including the Memorandum concerning the German problem, prepared by Mr. Odd Nansen. Executive Board, 21st session, Florence, 18 May. Paris: UNESCO. Accessed April 15, 2013, from http://unesdoc.unesco.org/images/0016/001622/162207eb.pdf. 
UNESCO (1951). UNESCO Courier, IV(1-2). Accessed April 15, 2013, from http://unesdoc.unesco. org/images/0007/000712/071298eo.pdf\#71298.

UNESCO (1958). Report of the Director-General on the activities of the organization in 1956. Paris: UNESCO. Accessed April 15, 2013, from http://unesdoc.unesco.org/images/0016/001605/ 160587eb.pdf.

UNESCO (1974). Records of the General Conference, 18th session. Volume 1: Resolutions. Paris: UNESCO. Accessed April 15, 2013, from http://unesdoc.unesco.org/images/0011/001140/114040E.pdf.

UNESCO (1976). Recommendation on the development of adult education adopted by the General Conference at its nineteenth session Nairobi, 29 November. Paris: UNESCO. Available online at http://unesdoc.unesco.org/images/0002/000278/027807eb.pdf [accessed 15 April 2013].

UNESCO (1986). Workshop of specialists in Europe on prevention of functional illiteracy and integration of youth into the world of work. 6 May. UNESCO Institute for Education. Federal Republic of Germany, 1-5 December 1986. ED-86/CONF.602/1. Paris: UNESCO. Accessed April 15, 2013, from http://unesdoc.unesco.org/images/0007/000723/072361eb.pdf.

UNESCO (2001). Proposals on an overall strategy for UNESCO Institutes and Centres and their Governing Bodies. 161 EX/41. Paris: UNESCO. Accessed April 24, 2013, from http://unesdoc. unesco.org/images/0012/001225/122582e.pdf.

UNESCO (2003). Decisions of the 166th session of the Executive Board (Paris, 4-16 April 2003). 166 EX/Decisions. Paris: UNESCO. Accessed April 15, 2013, from http://unesdoc.unesco.org/ images/0013/001302/130244E.pdf.

UNESCO (2006). Proposal to change the name of the UNESCO Institute for Education (UIE) to "UNESCO Institute for Lifelong Learning" (UIL), 174 EX/38 Rev. Paris: UNESCO. Accessed April 15, 2013, from http://unesdoc.unesco.org/images/0014/001448/144880e.pdf.

UNESCO (2012). Preliminary proposals by the Director-General concerning the draft medium term strategy (37 C/4) and draft programme and budget (37 C/5). Part I. 190th session of the Executive Board, Paris, 7 September. 190 EX/19 Part I. Paris: UNESCO. Accessed April 25, 2013, from http://unesdoc.unesco.org/images/0021/002175/217551e.pdf.

UNESCO Institut für Erziehung [sic] (1951). Erste Tagung des Kuratoriums. Bericht ueber die zweite Sitzung in Wiesbaden am 17. Juni 1951 um 15.00 Uhr. 1/UIE/GB - SR 2. Hamburg: UIL Archives.

Walters, S., Yang, J., \& Roslander, P. (2012). Study on key issues and policy considerations in promoting lifelong learning in selected African countries. Ethiopia, Kenya, Namibia, Rwanda and Tanzania. Tunis: Association for the Development of Education in Africa (ADEA). Accessed April 24, 2013, from http://uil.unesco.org/fileadmin/keydocuments/Africa/en/study-on-LLL_UIL_final_11-Jan-2012.pdf.

Watson, K. (1999). UNESCO's vision for education in the twenty-first century: Where is the moral high ground? International Journal of Educational Development, 19, 7-16.

Weindling, P. J. (2010). John W. Thompson. Psychiatrist in the shadow of the holocaust. Rochester, NY: University of Rochester Press.

\section{The author}

Maren Elfert is a Ph.D. student and research assistant in Educational Studies at the University of British Columbia. From 2001 to 2012, she worked as public relations and programme specialist for the UNESCO Institute for Lifelong Learning in Hamburg, Germany. 